Annuaire suisse de politique de développement

12 | 1993

Annuaire Suisse - Tiers Monde 1993

\title{
Le mécanisme suisse de désendettement - un bilan intermédiaire
}

Die schweizerische Entschuldungsfazilität - eine Zwischenbilanz

Rolf Kappel

\section{(2) OpenEdition}

1 Journals

Édition électronique

URL : http://journals.openedition.org/aspd/1434

DOI : $10.4000 /$ aspd. 1434

ISSN : 1663-9669

Éditeur

Institut de hautes études internationales et du développement

Édition imprimée

Date de publication : 1 février 1993

Pagination : 243-259

ISSN : 1660-5934

\section{Référence électronique}

Rolf Kappel, «Le mécanisme suisse de désendettement - un bilan intermédiaire », Annuaire suisse de politique de développement [En ligne], 12 | 1993, mis en ligne le 30 avril 2013, consulté le 08 septembre 2020. URL : http://journals.openedition.org/aspd/1434 ; DOI : https://doi.org/10.4000/aspd.1434

Ce document a été généré automatiquement le 8 septembre 2020.

(C) The Graduate Institute / Geneva 


\section{Le mécanisme suisse de désendettement - un bilan intermédiaire}

Die schweizerische Entschuldungsfazilität - eine Zwischenbilanz

\section{Rolf Kappel}

\section{NOTE DE L'ÉDITEUR}

En français, résumé seulement. Lire l'article original en allemand dans Schweizerisches Jahrbuch für Entwicklungspolitik : « Die schweizerische Entschuldungsfazilität - eine Zwischenbilanz ", http://sjep.revues.org/1253.

\section{RÉSUMÉS}

En juin 1990, six œuvres d'entraide avaient présenté une pétition demandant à la Confédération d'effectuer une remise de dettes aux pays les plus démunis à l'occasion de son $700^{\mathrm{e}}$ anniversaire. En mars 1991, les Chambres fédérales acceptaient l'ouverture d'un crédit-cadre de 400 millions de francs destiné au financement de telles mesures.

L'auteur compare brièvement le mécanisme mis en place par la Confédération et les opérations de désendettement menées en 1991-92 aux objectifs de la pétition des œuvres d'entraide. Se référant aux critères de la politique de développement et à la situation des pays à faibles revenus lourdement endettés, il analyse ensuite de façon approfondie trois grandes catégories de mesures : la réduction de la dette extérieure de pays s'engageant sur la voie des réformes, le rachat de créances privées par des institutions publiques et la création de fonds de contrepartie 
en monnaie locale destinés à financer la lutte contre la pauvreté.

Il apparaît finalement que la politique de réduction de la dette se justifie seulement dans une perspective à long terme. Les conditions pour la création de fonds de contrepartie sont rarement réunies, mais la lutte contre la pauvreté n'en est pas moins nécessaire.

\section{AUTEUR}

\section{ROLF KAPPEL}

Professor Dr., ETH, NADEL 